\title{
E-GOVERNMENT AND SECURITY OF INFORMATION INTERNET SOURCES
}

\section{E-GOVERNMENT AND SECURITY OF INFORMATION RELATED ORGANIZATIONS}

\author{
E-GOVERNMENT RELATED ORGANIZATIONS
}

\section{Institute for Electronic Government, IBM Corporation}

http://www-1.ibm.com/industries/government/ieg/

Founded in 1994, the IEG focuses on issues including public policy as it relates to technology strategy and execution, economic development and education, online citizen and business services, and e-democracy. A collaborative network of related government and technology organizations, academics and other research institutions forms the backbone of the IEG.

\section{The E-Gov Institute}

http://www.e-gov.com/

E-Gov is an accomplished organization of marketing and education professionals who have worked with technology leaders from government and industry for more than twenty years. The E-Gov team produces events throughout the year and publishes the E-Gov Digest.

\section{The Commonwealth Centre for Electronic Governance}

http://www.electronicgov.net/

The Commonwealth Centre for e-Governance (CCEG) is a think tank operating under the auspices of an e-Governance program of the Commonwealth Secretariat in London, UK. CCEG is a legal entity incorporated in the United Kingdom and Canada 
in November 2000. It operates on a global scale, with a board of Directors and Advisory Council from around the world. Members come from government, the private sector and civil society. The purpose of the Commonwealth Centre for e-Governance is to provide insight and knowledge on the changing nature of governments in the growing technology infrastructures. The CCEG is working to develop sets of best practices on how best to use technologies to implement the goals and objectives of public administration. It is the goal of CCEG to work with governments and international organizations to contribute to the growing knowledge base on e-Government, e-Governance and e-Democracy. Part of CCEG's mandate is to offer workshops and seminars in developing countries throughout the world on various aspects of eGovernment. Much of the focus of CCEG will be on the multitude of information and administrative policies that will be needed as developing countries increasingly implement new technologies. The site features news and events, research papers, workshop reports, presentations.

\section{E-Government - The World Bank Group}

http://www1.worldbank.org/publicsector/egov/

This is the World Bank's e-Government website focusing on e-Government in developing countries. The site features case studies.

\section{Digital Government Research Center}

http://www.dgrc.org/

Digital Government Research Center is a joint research center of the Information Sciences Institute at the University of Southern California and the Department of Computer Science at Columbia University. The center conducts research on computer technologies towards generating and sharing knowledge for government agencies.

\section{Center for Technology in Government}

http://www.ctg.albany.edu/

The Center for Technology in Government (CTG) works with government to develop information strategies that foster innovation and enhance the quality and coordination of public services. It conducts applied research and partnership projects on the policy, management, and technology issues surrounding information use in the public sector. The results generated by each project add to a growing knowledge base designed to support the work of both government professionals and academic researchers. The site contains a toolbox with starter kits, executive briefings, and step-by-step guides. 
Project output, research, demonstrations, publications and education programs are available on-line.

\section{Public Technology Institute, Inc.}

http://www.pti.org/

Public Technology Institute (PTI) is a U.S. non-profit technology research and development organization based in Washington, DC., representing local governments. The National League of Cities, the National Association of Counties, and the International City/County Management Association, three primary local government associations, provide PTI with its policy direction, while a select group of city and county members conduct applied R\&D and technology transfer functions. The Institute's mission is to bring the benefits of technology to local governments. Membership in PTI is open to all local governments.

\section{Kable}

http://www.kablenet.com/

Kable helps suppliers to understand the government market better and to reach public sector decision-makers. The company also helps government organisations to research the context of policy-decisions and to promote official guidance or consultation. Kable offers a combination of subscription and bespoke research, online and print publications, and a series of conferences and exhibitions. The company also offers customised event, publishing and research services for both public and private sectors customers.

\section{IDA}

http://europa.eu.int/idabc/en/chapter/3

The IDA (interchange of data between administrations) mission is to support the implementation of Community policies and activities by co-ordinating the establishment of Trans-European telematic networks between administrations. As data needs to be exchanged throughout Europe, IDA also acts as an important vehicle for the re-engineering of the working processes of the administrations. The work within IDA is performed through several action lines:

- Promoting the implementation of sectoral networks in priority areas of work

- Developing interoperability measures, for use by sectoral networks

- Extending the benefits of the networks to Community industry and citizens 
- Co-operating with national authorities and

- Co-operating with other EC services.

\section{INFORMATION SECURITY RELATED ORGANIZATIONS AND RESEARCH} INSTITUTIONS

\section{Computer Security Institute}

http://www.gocsi.com/

CSI is a leading membership organization specifically dedicated to serving and training the information, computer and network security professional. Since 1974, CSI has been providing education and aggressively advocating the critical importance of protecting information assets. CSI sponsors two conference and exhibitions each year: CSI NetSec in June; and the CSI Annual Computer Security Conference and Exhibition in November. CSI also offers a full schedule of training classes on encryption, intrusion management, Internet, firewalls, awareness, Windows and more.

\section{International Association for Cryptologic Research (IACR)}

http://www.iacr.org/

IACR is a non-profit scientific organization whose purpose is to further research in cryptology and related fields.

\section{Information Security Forum (ISF)}

http://www.securityforum.org/html/frameset.htm

ISF is a leading independent authority on information security. By harnessing worldrenowned expertise and the collective knowledge and experience of its membersincluding 50\% of Fortune 100 companies - the ISF delivers practical guidance and solutions to overcome wide- ranging security challenges impacting business information today.

\section{Computer Security Group, Computer Laboratory, University of Cambridge}

http://www.cl.cam.ac.uk/Research/Security/index.html

The Computer Security Group is an informal group of people with similar interests: mainly security, cryptology, and distributed systems. It holds meetings, seminars, and workshops. Computer security has been among the laboratory's research interests for many years, along with related topics such as cryptology, formal methods, medical 
information security, electronic commerce, steganography and information hiding, and the robustness of distributed systems in general.

\section{Computer Security Division, Information Technology Laboratory, National Institute of Science and Technology}

http://csrc.nist.gov/

Computer Security Division's main focus areas are: Cryptographic Standards and Applications, Security Testing, Security Research/Emerging Technologies, and Security Management and Guidance.

\section{Center for Education and Research in Information Assurance and Security (CERIAS) at Purdue University}

http://ciac.llnl.gov/cstc/

CERIAS is currently viewed as one of the leading centers for research and education in areas of information security that are crucial to the protection of critical computing and communication infrastructure. CERIAS is quite unique in its multidisciplinary approach to the problems, ranging from purely technical issues (e.g., intrusion detection, network security, etc) to ethical, legal, educational, communicational, linguistic, and economic issues, and the subtle interactions and dependencies among them.

\section{CSTC - Cyber Solutions Tools Center}

http://ciac.llnl.gov/cstc/

CIAC's Cyber Solutions Tools Center (CSTC), located at the Lawrence Livermore National Laboratory, provides solutions to U.S. Government agencies facing today's security challenges in information technology. They maintain information protection core-competencies through high-tech, integrated INFOSEC incident response, product development, and consulting services. The CIAC is composed of three complementary business units: Operational Incident Response; Advanced Security Projects; and Secure Systems Services. The Operational Incident Response group assists the Department of Energy in its information protection efforts by providing computer security incident response related services. The CIAC is composed of securitycleared information security professionals with backgrounds in computer science, information systems, and engineering specializing in awareness, training, and education; Electronic Commerce security; electronic security assessment; firewall and web security; incident response; Internet and Intranet security; intrusion detection; malicious code detection and eradication; network security; policies and procedures; risk management; and system and software engineering. 


\section{E-GOVERNMENT AND SECURITY OF INFORMATION RELATED RESOURCES}

\section{E-GOVERNMENT RESOURCES}

\section{E-Government Observatory}

http://europa.eu.int/idabc/en/chapter/140

The IDABC e-Government Observatory is a reference information tool on eGovernment issues and developments across Europe. It provides the community of eGovernment decision-makers and professionals with a unique set of information resources and with valuable insight into e-Government strategies, initiatives and projects in Europe and beyond.

\section{The Victorian Government's Repository of over 27000 e-Government Resources}

http://www.egov.vic.gov.au/

The e-Government Resource Centre aggregates substantial knowledge as to how the Victorian Government is meeting the goals of providing e-Government services to citizens. It is a very dynamic site.

\section{E-Government Resource Centre Canada}

http://www.egov.vic.gov.au/International/TheAmericas/Canada/canada.htm

\section{Downloads, Reports, Resources from the U.S. Federal Enterprise Architecture Program Management Office}

http://www.feapmo.gov/fea_downloads.asp

The site provides links to files and information resources that the reader may download to gain a better understanding of the purpose, usage, and definition of the Federal Enterprise Architecture and associated reference models. These include standard text documents as well as files that one may download in XML format which contain the models of the Federal Enterprise Architecture. Data within the XML documents can be integrated into external datastores, data management systems or applications. As the Federal Reference Models evolve there will be subsequent releases of the Federal Enterprise Architecture in XML format. As new resources are created, the FEA-PMO will post these links to the "What's New" section on the FEA- 
PMO homepage. These downloads have been organized by category of FEA-related information.

\section{Piper Resources}

http://www.statelocalgov.net/

State and Local Governments on the Web is a frequently updated directory of links to government sponsored and controlled resources on the Internet. It was created by Piper Resources, an Internet publishing firm, which has been providing the guide to the public for five years.

\section{E-Government and e-Commerce Resources and Articles}

http://www.mrsc.org/Subjects/InfoServ/egovresource.aspx

\section{Asia-Pacific e-Government Portal}

http://www.egovaspac.org/

\section{UNPAN e-Government Theme}

http://www.unpan.org/egovernment.asp

The site provides a very wide collection of presentations, links and resources, tools and papers.

\section{International Telecommunication Union - e-Government}

http://www.itu.int/osg/spu/wsis-themes/ict_stories/egovernment.html

Case studies on using information and communication technologies to bridge the digital divide.

\section{SECURITY OF INFORMATION RESOURCES}

\section{Information Security Resource Centre}

http://www.pnl.gov/isrc/

The Information Security Resource Capability (ISRC) is located at the Pacific Northwest National Laboratory (PNNL), in Richland, Washington. The ISRC provides support to the Department of Energy (DOE) Security Policy Staff in the Office of Security. The ISRC has served as a Center of Excellence for information security 
issues for more than 12 years. The ISRC provides programmatic and technical support in the areas of Information Security, Facility Surveys and Approvals, Foreign Ownership, Control, or Influence, and maintains the DOE Incident Tracking and Analysis Capability (ITAC). These activities support the development of costeffective, risk management-based security measures for incorporation into DOE Safeguards and Security Policies. The ISRC provides the DOE Security Policy Staff with expert technical assistance on critical Information Security matters across the DOE Complex, has developed effective Information Security training courses, provides subject matter expertise in policy planning and development, and provides an array of security technologies.

\section{Research Resources on Authentication, Digital Signatures and PKI Issues}

http://www.egov.vic.gov.au/Research/Authentication/authent.htm

\section{Computer Security Resources from National Security Institute (NSI)}

http://nsi.org/compsec.html

This web site features alerts and warnings, papers, programs, FAQs, government standards, mailing lists and newsgroups, computer security links, legislation, manager's guides, etc.

\section{Computer Security Information}

http://www.alw.nih.gov/Security/security.html

This page features general information about computer security. Information is organized by source and each section is organized by topic. The site includes FAQs, newsgroups, mailing lists, documents, programs, advisories, electronic magazines, newsletters, news sites, web sites, etc.

\section{ITtoolbox Security}

http://security.ittoolbox.com/

ITtoolbox Security offers forums for discussion, an integrated directory, daily news, and many other services geared towards security professionals and users of security products. 


\section{E-GOVERNMENT RELATED PROJECTS AND INITIATIVES}

\section{eEurope Awards}

http://www.e-europeawards.org/

The eEurope Awards recognize innovative initiatives in the areas of e-Government and e-Health within Europe. The overall goal of the eEurope Awards is to promote best practice among the Member States of the enlarged European Union, the candidate countries as well as the EFTA countries. This will facilitate the sharing of experience and mutual learning from each other in order to meet the Lisbon targets and make Europe the most competitive knowledge-based economy by 2010 .

\section{The Official Web Site of the U.S. President's e-Government Initiative http://www.whitehouse.gov/omb/egov/}

\section{“Secure e-Government" Project}

http://www.bundonline2005.de

http://www.staat-modern.de

The "Secure e-Government" project interacts closely with the German government's BundOnline 2005 e-Government Initiative and the "Modern State - Modern Administration" program. Further information is available from the above sites.

\section{New Zealand e-Government Programme Home Page}

http://www.e-government.govt.nz/

\section{E Project at Harvard's Kennedy School of Government}

http://www.ksg.harvard.edu/exec_ed/3e/

This is the homepage of the 3E Project at Harvard's Kennedy School of Government. The E-government Executive Education (3E) project at Harvard's John F. Kennedy School of Government is a collaborative effort among public- and private-sector organizations to inform and strengthen the leadership and cross-boundary relationships needed for $21^{\text {st }}$ century government and governance. The project focuses on innovation through the use of information technologies. It offers services and content through a combination of traditional classroom interactions and network-enabled distance education. 


\section{Government Management Information Sciences (GMIS)}

http://www.gmis.org/index.html

The purpose of GMIS is to provide a forum for the exchange of ideas, information, and techniques; to foster enhancement in hardware, software and communication developments as they relate to government activities.

\section{Access e-Government - an Educational Program}

http://www.access-egov.info/

The site is a starter kit for e-Government webmasters that shows local governments how to find resources and how to plan information-rich websites towards transact business and communicate with their citizens.

\section{The National Science Foundation's Digital Government Research Program} http://www.diggov.org/

The Digital Government Program funds research at the intersection of computer information sciences and government information services, with the goal of bringing advanced information technology to the government information community. These Government/academic collaborations should contribute to government strategic planning for information services while providing interesting and unique new research problems and data sets for the academic research community. The site contains links to project demonstrations.

\section{DigitalGovernance.org Initiative}

http://216.197.119.113/artman/publish/index1.shtml

The site features models of digital governance, case studies, publications and events.

\section{Global Business Dialogue on e-Commerce}

http://www.gbde.org/egovernment/

This database contains projects, experiences and best practices on e-Government classified by region/country. 